\section{Behaviour Therapy and the Neuroses}

Edited by H. J. Eysenck, PH.D. Pp. xi +479 . Oxford, London, New York and Paris: Pergamon Press. 1960. 63s.

This book constitutes yet one more broadside in the long campaign waged with evangelical zeal by Professor Eysenck and his group against unscientific thinking and practice in the field of abnormal psychology. Psychoanalysis at its inception brought into being a new technique for the exploration of the human mind. If it had confined itself to scientific enquiry the history of the psychoanalytical movement, and perhaps of psychiatry itself, might have followed a different path. It became instead, at a relatively early stage, a means by which those trained in psychoanalysis earned their livelihood. The benefits which have flowed from the half-century of practical application of Freud's teaching which followed have been disputed. They are held to be indubitable by many psychoanalysts; they have been called into question with vigorous iconoclasm by Professor Eysenck and his school. As far as dispassionate scientific enquiry into Freudian theories is concerned, there can be little doubt that their early clinical application on a wide scale has had unfortunate effects.

The present volume has brought together contributions from a number of workers who describe some alternative approaches to the treatment of mental disorder. These are held to be based on sound scientific principles, susceptible to experimental evaluation effective and economical. The theoretical background of all the contributions is derived from learning theory, probably the most highly developed and precise branch of psychology, whose postulates have been expressed by Hull in mathematical terms. The present volume contains contributions on the various methods of treatment: reciprocal inhibition, negative practice, aversion therapy and positive conditioning and a section on the theoretical bases of the subject.

The most impressive body of practical work in this field has probably been carried out by Wolpe, whose experience derives from an impressive clinical material of 122 cases; he claims that $90 \%$ were cured or greatly improved by his methods, a rate of success substantially higher than that reported from psychoanalytical sources. There are other articles of considerable interest on the treatment of stammering, phobias, writer's cramp, homosexuality and enuresis. There can be little doubt that these endeavours have exerted a beneficial and invigorating effect in that they have led those concerned with the treatment of neurotic disorders to question many of their basic assumptions. They have also helped to focus attention on the current disabilities of those afflicted with neurotic disturbance. It seems undeniable in the light of recent experience that, contrary to the expectations of psychoanalysts, many patients can be given relief, which is at times lasting, by methods of treatment directed towards their presenting symptoms where a more thorough-going approach through the historical events that have helped to make them vulnerable fails. This book should therefore be on the shelf of every practising psychiatrist.
The scientific evaluation of such successes is, however, another matter. Most of the authors appear to have overlooked, or conveniently forgotten, the evidence cited by Professor Eysenck elsewhere, that some $70 \%$ of neurotics recover spontaneously in two years. It need hardly be said that no practising psychiatrist who takes the trouble to follow up his patients will take this figure seriously. But one would have expected the authors of a book such as this to lean backwards far enough to make generous allowances for it. They cannot expect to be exempt from the criticism with which they castigate psychoanalysts that their methods of treatment have not been submitted to controlled trials. Criticism is disarmed to some extent by a certain caution in drawing conclusions, but they would carry more conviction if the attempts made to show that the patient's behaviour conformed to theoretical expectation had a less procrustean quality in several papers.

One phobic patient, who is stated to have recovered from her symptoms following a treatment based on learning principles, died three days after her last interview in one of her 'blackouts'. From the account given, death was likely to have been due to vagal inhibition. One could not perhaps expect a psychologist to be aware that the blackouts may well have been an integral part of the phobic state. But the scientific naiveté that is reflected by a failure to consider the possibility that recovery had not been as complete as imagined by the therapist is little short of alarming. This is, nevertheless, a valuable and stimulating book.

\section{Sedan's Re-educative Treatment of Suppression} Amblyopia

T. KeITh Lyle, C.B.E., M.D., M.CH., M.R.C.P., F.R.C.S., Cynthia Douthwaite, D.B.o., and JiLL Wilkinson, D.B.o. Pp. 135. Edinburgh and

London: E. \& S. Livingstone. 1960. 25 s.

This book is an abridged English version of Jean Sédan's book, 'Post Cure de L'Amblyope Rééduqué'. Jean Sédan has made a valuable contribution to the treatment of amblyopia exanopsia. The book contains a series of visual exercises which aim at improving the visual acuity by overcoming the inhibition of amblyopia. For those patients with disturbances in spatial localization (eccentric fixation) the exercises are of value after central fixation has been restored by the Cüppers technique. The exercises are designed to make the patient concentrate on the printed matter and to stimulate his attention, power of discrimination and sensorial co-ordination.

The book is well produced and it will be appreciated by ophthalmologists and orthoptists who are interested in the treatment of amblyopia.

Hæmopoiesis, Cell Production and its Regulation

A Ciba Foundation Symposium. Edited by G. E. W.

WOLSTENHOLME, O.B.E., M.A., M.B., M.R.C.P., and Maeve O'ConNoR, B.A. Pp. 490 + xii, with 107 illustrations. London: J. \& A. Churchill. 1960. 60s.

From February 2-4, 1960, 27 experts in cell production and its regulation met in London under the auspices 